Historic, Archive Document

Do not assume content reflects current scientific knowledge, policies, or practices. 



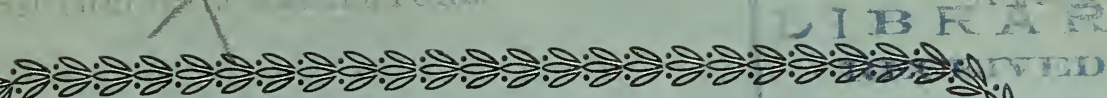

ANNUAL PRICE LIST Ty

of SMALL FRUITS and

VEGETABLE PLANTS 


\section{NINETEEN HUNDRED AND SEVENTEEN.}

The past year was, in some respects, a most trying one for the plant grower. Over a great part of the country the extremely dry weather lasted most of the summer. This, and the very hot weather part of the time, made growing and shipping plants a hard proposition. Try as hard as we could and we had to disappoint a few customers because we were short on some varieties of plants.

This year we hope to profit by experience, and shall try to grow a large stock of plants.

In writing this little catalogue I have tried to make the description of varieties as brief as possible and not overdraw. I have not used cuts or testimonials, as they only serve to fill space and add to expense, and all extra expense must add to the price of plants. My experience teaches me that satisfied customers are the best advertisement I can have and I am conceited enough to think I have a long list of that kind.

Wishing all my friends and patrons a prosperous season.

Respectfully,

S. C. ATHERTON. 


\section{EARL $Y$ CABBAGE PLANTS.}

Cabbage plants are a specialty with me and I try to grow and have for sale a constant supply of them from last of March until middle of August.

Seed of first early varieties is sowed in greenhouse Jan. 1st. Plants are planted in cold frames first of March and are usually readr to sell last of March. From this time on we make continuous sowings of seed in open field until end of season.

\section{Varieties of Early Cabbage This Season:}

Early Jersey Wakefield, Winningstadt, Henderson's Early Summer, Chas. Wakefield, Early Flat Dutch.

\section{Price of Early Cabbage Plants:}

Readr about March 20. Transplanted and hardened. Plants 40 cents per $100 ; \$ 3.50$ per 1000 .

Sash grown plants, not transplanted, ready about April 20. 30 cents per $100 ; \$ 2.50$ per 1000 .

Early plants grown in open field, ready about May 10.15 cents per $100 ; \$ 1.00$ per 1000 .

\section{LATE CABBAGE PLANTS.}

I grow and sell a large quantity of Late Cabbage Plants each season. Sow seed at different times so as to have a supply of plants at all times from May 20th until August. Will have the following varieties this rear: Danish Ball Head, Late Flat Dutch, Autumn King, Surehead, All Seasons.

\section{Price of Late Cabbage Plants:}

15 cents per $100 ; \$ 1.00$ per $1000 ; 5000$ or more at 80 cents per 1000 .

\section{CAULIFLOWER.}

I will try to have plants of Early Snowball ready about May 15 and keep them in stock until July.

For late planting will have Teitches Autumn Giant. Readr about July 1st, until Aug. 15.

\section{Price of Cauliflower Plants.}

Early Snowball, 35 cts. per 100; \$3.00 per 1000. Autumn Giant, 30 cts. per 100: $\$ 2.50$ per 1000 . 


\section{EARLY TOMATO PLANTS.}

We start our Early Tomato Plants in greenhouses, sow the seed about March 1st and when plants are large enough transplant into cold frames to harden them and usually have them ready to set in open field by May 5th. Tomato plants cannot endure frost, even when well hardened and should not be set in field until danger of frost is past, unless they are to be protected.

\section{Varieties:}

Spark's Earliana.-Now well-known everywhere. One of the earliest. Bright red, fairly smooth, although not as smooth as some of later varieties, medium in size and good quality. One of the best early varieties and popular with market gardeners everywhere.

Chalk's Jewell.-A good second early variety, about one week later than Spark's Earliana. Smoother, and better shape. A heavy cropper. Plant a very strong grower and continues to bear for a long time. Some prefer this for the early market.

John Baer.-This is a second early variety. It is a week later than Earliana, but is one of the finest tomatoes I ever grew. Medium in size, very smooth and solid, bright red in col$\mathrm{or}$, and remarkably free from cracks. Vine healthy and remains in bearing a long time. If I was confined to one variety for garden I should choose this one.

\section{Prices of Early Tomato Plants.}

60 cts. per $100 ; \$ 5.00$ per 1000 .

We cannot send Tomato Plants by mail.

\section{LATE TOMATO PLANTS.}

We grow them in large quantities for truckers and canners. 'They are grown in open field, not transplanted, but good stocky plants. This season we shall grow these varieties: Stone and Success. Ready about June 1st.

\section{Prices of Late Tomato Plants.}

20 cts. per $100 ; \$ 1.25$ per 1000 . They should always be sent by express. Plants ready about June 5th.

\section{CELERY PLANTS.}

I have a large trade in celery plants and ship them in large quantities over a wide extent of territory. 


\section{Varieties.}

White Plume, Golden Self Blanching, Giant Pascal, Winter Queen and Golden Heart. Plants ready about July 10th.

\section{Prices of Celery Plants.}

Golden Self Blanching, 25 cts. per 100; \$2.00 per 1000 .

All other varieties, 20 cts. per $100 ; \$ 1.50$ per 1000 .

The high price on Golden Self Blanching is owing to the fact that the seed from this variety is imported from France and is very high in price.

\section{BEET PLANTS.}

Last year we were a little late in getting our Beet plants ready, and could not fill all our orders on time.

This year we shall try hard to grow enough for all orders and have them ready on time. Will grow same varieties as last year. Early Blood Turnip and Crosby's Improved. Plants ready about May 15̃. In stock until July 1st.

\section{Price of Beet Plants.}

20 cts. per $100 ; \$ 1.25$ per 1000 .

\section{SWEET POTATO PLANTS.}

Gold Skin.-This is the most popular variety grown in this section. A tremendous yielder, a bright yellow skin and yellow clear through, very rich and good flavor, not quite so good a keeper as some others but can be kept all winter when temperature is right. I can recommend this as one of the very best for market or house use.

Up River.-This is a comparatively new variety, yellow, does not yield quite so well as Gold Skin, but is perhaps a little better keeper and for this reason is preferred by some. It is also claimed by some that the variety does not grow so large and sells better in market.

Red Nansemond.-This is the best red variety that I know anything about, very smooth, good shape, medium size, and a good keeper. For those who like a dry potato this is the very best in eating qualities. It does not usually sell quite so well in the city markets, as the yellow variety, but for home use it has no superior.

\section{Prices of Sweet Potato Plants.}

20 cts. per $100 ; \$ 1.50$ per 1000 . If ordered to be sent by mail add 12 ets. per 100 for postage. Plants ready about May 10. 


\section{EGG PLANTS.}

I have a constantly increasing demand for the plants of this delicious vegetable, and I grow and sell many thousand of them every year. This season I will have two varieties, New York Purple and Black Beauty, both very nice purple varieties. Black Beauty is a few days the earliest.

\section{Prices of Egg Plants.}

15 cts. per dozen; 60 cts. per $100 ; \$ 5.00$ per 1000 . Eg' Plants ready about May 1.

\section{PEPPER PLANTS.}

Ruby King:- The most desirable and popular of the large mild peppers and in great demand in the city market. It is a brilliant red color and grows to a good size.

Red Cayenne.-This is a small and very hot pepper much used in making pickles, soups, etc. It is a strong grower and a heavy bearer.

Chinese Giant.--One of the largest peppers grown. Fruit very handsome in appearance, mild and sweet. It is pronounced by all who know it to be one of the best.

\section{Price of Pepper Plants.}

10 cts. per dozen; 50 cts. per $100 ; \$ 4.00$ per 1000 . Plants ready about May 1.

\section{How to Treat Plants on Arrival.}

When plants arrive in a wilted condition, unpack them at once and put the roots into a bucket of cool water for an hour. They will generally revive and be in condition to set in ground.

\section{ASPARAGUS ROOTS.}

Palmetto.-This is the leading variety grown in all sections both for market and family use. Grows to large size and sells for highest price in the market.

Giant Argenteuil.-A new French variety not so well known in this country but said by some to be larger than Palmetto. I have had no experience growing this variety except for plants.

\section{Price of Asparagus Roots.}

One rear roots, 30 cts per $100 ; \$ 2.50$ per 1000 . Two year roots, 35 cts. per $100 ; \$ 3.00$ per 1000 . 


\section{RHUBARB ROOTS.}

This year I have only 2 year roots, they are large, strong' roots, grown from seed. Tariety "Simnaens."

Rhubarb or Pie Plant is one of the easiest of all vegetables to grow and it comes very early in the spring. It is a very desirable acquisition to any garden.

\section{Price of Roots.}

35 cts. per dozen; $\$ 2.00$ per $100 ; \$ 15.00$ per 1000 . 


\section{STRAWBERRY PLANTS.}

I have been a grower of strawberries for 30 years and most of this time I have been growing and selling strawberry plants. I have grown all the different varieties as they came along. Of course some of the new varieties did not possess merit, but others have proved to be very valuable, and have been money makers for thousands of people.

In all my experience I have never known so many valuable new varieties as we have at the present time, such varieties as Chester, Kellogg's Prize, Joe Johnson and Bayside are bound to become popular over a wide territory and become standards like Gandy and Chesapeake.

I have a large stock of plants this year, both Fall and Spring bearing. I am prepared to supply my customers with as good plants as can be grown anywhere and at very reasonable prices.

Chester.-Here is a new berry that I want all my customers to try. When I say, I have been growing strawberries for 30 years, and this is the finest berry I ever saw, you may think I am putting it too strong, but when you have seen the berry you will say the same.

During the season of 1915 I received a letter from a prominent fruit grower of Kent County, Del., saying that he had a wonderful strawberry to show me and inviting me to visit him. When I reached his town he met me at the station with his team and took me out to his farm, his picker's were picking Chester berries that day. I thought I had seen nice strawberries before but I had never seen anything that equaled this. The vines were heavily loaded with the largest strawberries that I ever saw. This man had other good varieties, among them Chesapeake, but the Chesapeake was no comparison to Chester in size or productiveness. 'I made another visit to this same field about the time of the last picking,' and the berries were still very large, showing that the berry was holding up well in size all through the season. ' Before leaving' that day I bought ten thousand plants of the Chester, to be delivered in the Spring of 1916. These plants were shipped to me in due time and now I have about two acres of them that are very nice.

The Chester originated at Chester, Pa., and has been grown for several years by two or three men, in Kent County, who are expert berry growers. They had never sold many of the plants before this time, and the berry is very little known except by these growers. 


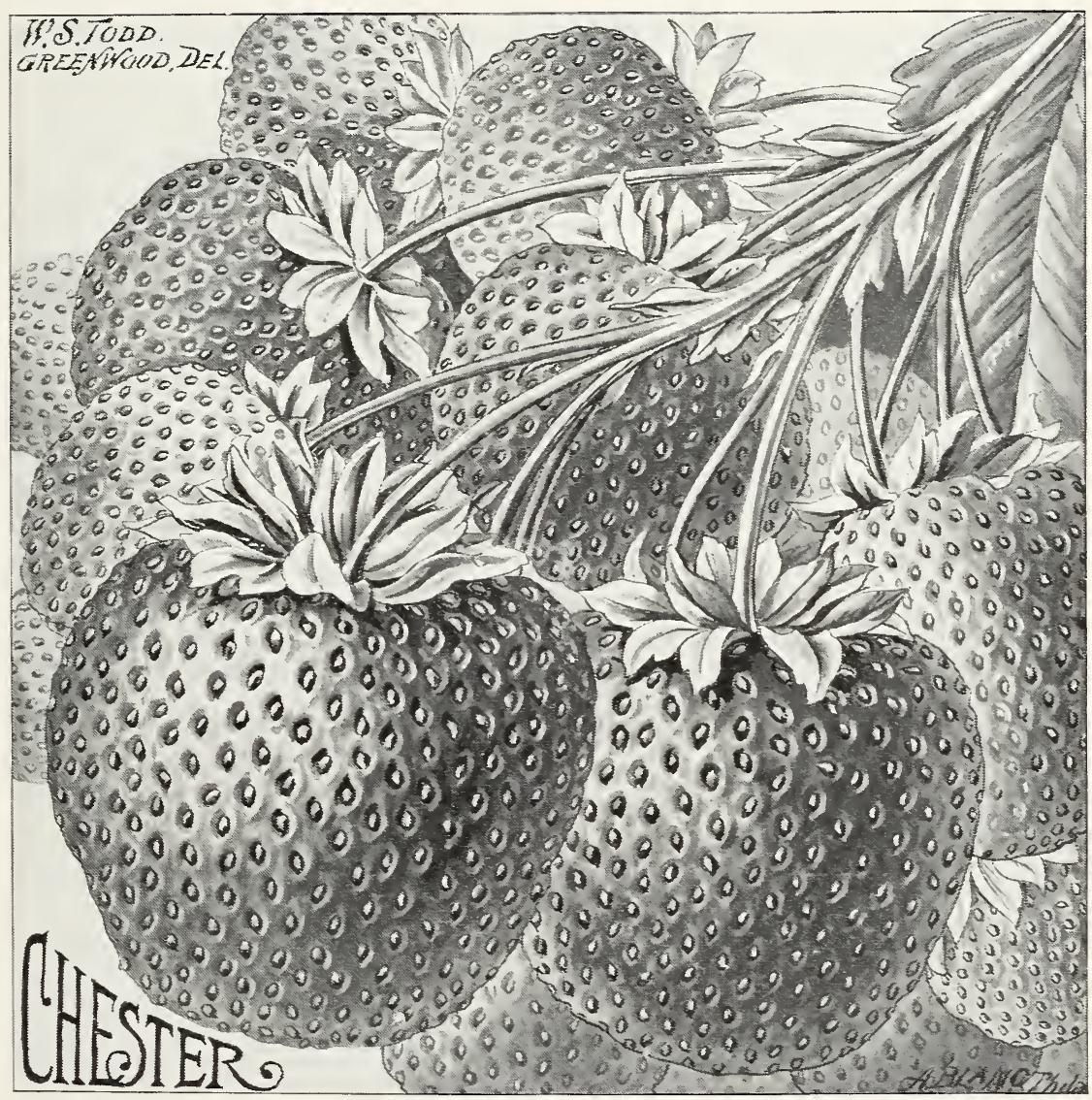

It is a mid-season variety, ripening a fer dars before Chesapeake, perfect in bloom, makes good beds of vert large, deep rooted, healthr plants. ' I have nerer been very enthusiastic orer new rarieties, until I had tested them thoroughls, and I hare tried manc new ones that were a disappointment, but if the Chester does not prove to be one of the best rarieties, I lose mr guess. I have a rery large stock of plants of this rariets and mould like all mr customers who grow stramberries to give this a trial. I have made the price rery low.

Bubach.-This is one of the old standard rarieties that has stood the test for more than trentr rears. It needs no description as it has been fruited in all parts of this countre and in some sections is still a leading standard rarietr. It is imperfect in bloom and with me is perfectlr healthr and makes plenty of plant for a good fruiting bed. 
Gandy.-This well known variety, which has been grown in this vicinity for nearly twenty years, is still the favorite late variety, both with grower and buyer. To those not familiar with the berry, I would say it is a late variety, large in size and bright red in color. The berry is of an unusual firmness, and can be shipped to distant markets, arriving in fine condition. It is also a good variety for canning and preserving, having an excellent flavor. It is a strong, vigorous grower, entirely free from rust. It succeeds best in low, moist soil.

Chesapeake.-This variety is now so well known that it does not need any description. It has been thoroughly tested everywhere and has proved to be one of the most popular varieties ever grown.

It is very large, solid, and a heavy bearer. Its only serious drawback is, that it is a hard variety to grow, requiring especial care and rich soil to get best results.

Superior.-A very good midseason variety. Although it does not suceeed in all section, it is one of the money makers here. Its good points are: firmness, good color, regular shape, and heavy bearer. Although not as large as some varieties, with good culture it will produce a large crop of medium size, very solid berries which carry well to distant markets. The vine is a very strong grower and should be kept thinned or the beds will get too thick, causing the fruit to be undersized.

Klondyke.-One of the first of the mid-season varieties to ripen. The fruit is perfect in shape and very firm, growing on a long stem well up from the ground. The vine is one of the strongest growers and is apt to bed too thickly. This is a very popular variety especially in the south and one that I can highly recommend.

Lady Cornell.-This berry I fruited in a small way for first time last year and I should say it was a good variety of the Klondyke type. It originated in the south where it is said to be very popular and a better berry than Klondyke. The plant is a very strong grower, making heavy beds of strong, healthy looking plants. Berry is medium in size, somewhat conical in shape, uniform in size, and holds up weil on in the season's fruit; quite firm and suited for distant market.

St. Louis.-Another early variety with one serious fault, it is quite soft. Almost as early as Excelsior, as large as Bubach, bright red color, vine strong grower, perfectly healthy, for home use or nearby market it is all right, but too soft for long shipment. 
Fendall.-Came from Maryland, has been extensively advertised and great claims made for it. I have now fruited it two seasons; with me it has many good points in its faror but it is rather light in color and not very solid, othherwise it is all that could be desired. It ripens just ahead of Gands, is very large, and produces an immense crop of fruit, foliage strong and healthy, good plant maker, light green in color. I know of no variety that will produce more plants per acre than this one.

Glen Mary.--In the northern states this has been a standard and raluable variety for nearly twenty year's, produces immense crops of large, solid berries, fine flavor and good color. When a variety has stood the test for 20 years like Glen Mary has it needs no further description. I always have a good sale of this variety.

3 W's.-A good mid-season variety covering a long season, quite large and solid, medium heary bearer, vine a strong grower, making very large, deep rooted plants. In some sections rery popular.

Myers No. 1.-This is a late variety that originated in this county and if it were only a little more solid it rould stand about at the head of the list of late varieties. Bears very heary crops of beautiful bright red, perfect shaped, large size berries. Thile it is not so soft as some varieties I think it is about like Bubach in firmness. It is grown extensively in this county and has made big money for the growers.

Wm. Belt.-This is the standard for quality the country over. No lover of fine strawberries should omit this from his list of beries for family use. Its large size and fine flavor have made friends for it everywhere, in spite of the fact that it is somewhat subject to rust. The plants are alwars in demand although it has been known and grown for years.

O. I. C.-This is a mid-season variety. It produces a good crop of large conical, pointed berries, quite firm, good color, and a good all around variety. It makes very large, strong plants with heavy foliage which protects the fruit in good shape. The fruit ripens about the same time as Bubach.

Mascot.-This is a late variety which greatly resembles Gandy, both in plant and fruit. It is not quite so regular in form as Gandy and not quite so solid. It will probably bear a little heavier crop than Gands, especially on high land. After giving it a fair trial, I don't think it can compete with Grandy in this locality. 
Paul Jones.-This is a late variety which is extremely popular in the West. It bears an immense crop of medium size, bright red berries, somewhat pointed in shape; very solid. Plant a ver'y rank grower, is apt to bed too thick on good land. Should be kept thinned out to secure good size fruit. Blossom imperfect.

Heritage.-This is one of the big fellows, it belongs to the class of Corsican, New York, Marshall, ete., but with me it is a better bearer. It does not produce such heavy crops as some of the smaller varieties but produces medium crops of very large, somewhat irregular, fairly solid berries, ripens mid-season, and in some sections very popular. Not grown to any great extent here.

Senator Dunlap.-This is one of the old standard midseason varieties. It has been tested for years in all sections and succeeds everywhere. It produces large crops of medium size, very smooth, dark red berries, quite solid. Vines are very rank growers, and should be kept thinned, otherwise berries will be undersized. Plants of this variety are always in demand, showing that it is quite popular everywhere.

Sample.-This is an old and well known variety, having been fruited for 10 or 12 years. The plants are always in demand, proving that it is a profitable variety over a wide territory. It is an imperfect blooming variety ripening a little after midseason, produces very large crops of large nice shape berries, only medium in firmness. Vine a good strong grower, but in hot dry weather it sometimes rusts a little in this locality. Succeeds best on rather low moist ground.

Bayside.-This is a splendid new variety which originated at Bridgeville, Del., a few years ago, and where it is fast becoming a popular market variety. It is a mid-season variety, ripening two or three days later than Superior. Is nearly as large as Gandy; very smooth and round; solid enough to be a good shipper. Color dark red, and very attractive. Has a large green cap which adds to its appearance. Bears a very heavy crop. Vine a very rank grower and free from rust. Decidedly a good variety for market or home use.

Joe Johnson.-After fruiting this variety two seasons, I can hardly say enough in its favor. It is certainly one of the money makers in this section; about size of Gandy, very solid, and smooth; makes a strong growth of large, healthy plants, which bear a medium crop of the finest fruit. It ripens a week earlier than Ganby. In quality and size, equal to Gandy. It will sell for top price in any market. 
Parson's Beauty.-This berry somewhat resembles the wellknown Bubach in size and shape but a little darker in color. It is a good solid berry. The vine is a strong vigorous grower, making verr large plants. The berries have short stems and should be mulched with straw or other material if grown on sandy land. It is a heavy cropper, berries growing to a very large size. It is also an excellent table berry. These and other good qualities make it a very profitable berry for growers. Does best on low moist ground.

Tennessee.-This old variety is too well-known everywhere to need a description. Fifteen years ago it was the standard rariety in this section and was grown by the hundred acres, and it made money for the growers. Now other varieties have taken its place to a great extent, but it still is just as fruitful as ever and it is hard to find a variety that will produce as many quarts per acre with ordinary care as Tennessee. Its only fault is it is not a first class shipper, being rather soft.

McAlpin.-This is a new variety of more than usual merit. The fruit greatly resembles Gandy in size, shape and firmness, and is a much heavier cropper than Gandr. The plant is also a much stronger grower than Gandy. Will suceeed on almost anc kind of soil; commences to ripen a week earlier than Gandy and remains in fruit a long time.

One New York Commission Merchant said of it: "McAlpin Is the finest berry we have ever sold, and we know what good berries are. We sold them at 23 cts per qt. wholesale."

While I have only fruited it once, and then in a small war, I should say it is a very valuable varietr, and has come to star. Hope my customers will give it a trial.

Early Jersey Giant.-Is not quite so early as Excelsior and St. Louis, but it is a very large berry and quite solid. Berry somewhat conical in form, very bright red in color and good eating quality; plant an extra strong grower, with large healthhy foliage free from rust. I consider this a very good early variety either for market or home use and hope my customers will give it a trial.

Kellogg's Prize.-This new varietr, introduced by Mr. Kellogg, of Michigan, seems to be just what we have been looking. for for a long time- that is, a good, imperfect variety. It has more good qualities than nine-tenths of the varieties that I have fruited. Good size, solid, heary cropper, and a strong grower. I should judge that a field of this varietr, fertilized with Joe Johnson, or Chesapeake, would be about the best of anything in strawberries. Be sure to try this one. 
Rewastico.-This is a highly-colored Cardinal red berry of high quality, and quite firm. Berries are uniformly large in size and very nearly perfect in shape. Plant a strong grower, making heavy bed of large healthy looking plants, free from rust.

It is claimed by some that this berry is a strong competitor with Chesapeake, while it is much easier to grow than Chseapeake.

\section{THE EVERBEARERS.}

The Fall Bearing or Everbearing stawberry is no longer an experiment as they have been tried in all parts of the country. While they may not be a profitable crop to grow where one is a long distance from market, they will certainly bear plenty of berries in summer and fall, and no garden is complete without a few of them for family use, and in all sections located near large towns and cities they have proved to be very profitable as a money crop.

I have tried all the leading varieties as they were introduced, but have discarded all but two varieties Progressive and Superb. These are recognized as the best yet introduced in all parts of the United States.

Progressive.-With me this is the best of the Fall bearers. It should be set on rich land then it will produce plenty of fruit from July 1 until freezing weather and at same time make a good bed of plants.

The fruit is only medium in size, about like Dunlap, quite solid and very sweet in flavor. Blossoms should be kept cut off until middle of Jume to give plants a chance to start growing, otherwise they are injured by bearing too much.

Superb.-Next to Progressive I consider this best of Fall bearers, and is preferred, by some, to all other varieties. It is a larger berry than Progressive but not quite so good flavor. 'J'liis variety should be grown by hill method to do its best.

It is a favorite variety with the fruit growers in the northern states, because of its large size and fine appearance. It brings fancy prices in the large cities. 


\section{READ BEFORE ORDERING.}

Cash is required with all orders, and remittances should be made by Post Office Money Orders, Express Orders or Registered Letter. One and two cent stamps received for small amounts.

Orders may be booked in advance, held a reasonable time and sent on remittance.

How We Ship: Unless otherwise ordered, we usually ship, all orders by Express, but large orders can be safely sent, early in the season by freight. If for only short distances can send small orders of small plants by mail in perfect safety. Purchasers to par transportation charges in all cases.

Mistakes. I very seldom have any complaint on this lime, as all possible precautions are taken to aroid mistakes. Nntify me at once if your order is not properly filled and I will rectify all mistakes. My customers may depend on getting full count of good live plants.

Packing: I make no charge for boxing and packing. All plants are delivered on cars at Greenwood at prices given.

Time to Order: It is best for purchasers to send their orders early and have them booked ahead as I am sometimes sold out of some varieties before the season is over. It is also best to set strawberry plants just as soon as it is possible to prepare the land as they will then live much better and transportation charges are then lighter than later in the season when plants have made a larger growth.

Lost Orders: Every order will be acknowledged by card at once, so if you do not hear from me in a few days write me again and the matter will be investigated.

STATE OF DELAWARE.

\section{STATE BOARD OF AGRICULTURE.}

\section{CERTIFICATE OF NURSERY INSPECTION.}

To Whom it may Concern:

Dover, Delaware, September 14, 1916.

This certifies that I have this day examined the nursery stock and premises of the.............................................................. Atherton, at Greenwood, Sussex county, Delaware, and that said nursery stock is apparently free from crown gall, peach vellows, peach rosette, the San Jose scale, and all other plant diseases and insects of a seriously dangerous nature, that may be transferred on nursery stock.

This certificate may be revoked by the State Board of Agriculture for cause, and it is invalid after August 31,1917 , and does not include nursery stock not grown on the above named premises unless such stock is covered by certificate of a State or Government offcer and accepted by the State Board of Agriculture. WESLEY WEBB, Inspector. 


\title{
PRICE LIST OF STRAWBERRY PLANTS.
}

\author{
By Express \\ Charges Collect \\ Per 100 Per 1000
}

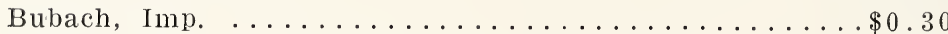

$\$ 2.75$

Bayside, Per.

2.50

Chesapeake, Per. .....................40

3.50

Chester, Per.

Early Jersey Giant, Per.

Gandy, Per.

Glen Mary, Per.

Haverland, Imp.

Heritage, Per

Joe Johnson, Per

Kellogg's Prize, Imp

Klondyke, Per.

2.50

Lady Cornelle, Per.

Meyer's No. 1, Imp.

McAlpine, Per.

Mascot, Per

O. I. C., Per



Progressive, Per., (Fall Bearing)..............60

Rewastico, Per.

Superb, Per., (Fall Bearing) ............... 60

Senator Dunlap, Per. .....................25

Sample, Imp.

St. Louis, Per.

Superior, Per.

Tennessee, Per.

Wm. Belt, Per.

\section{0 at 100 Rate. 500 at 1000 Rates.}

The price given for 500 to 1000 is for that quantity of one variety. Less than 500 of one variety must be paid for at 100 rates.

If Strawberry Plants are ordered by mail send postage enough for 4 pounds per 100 plants, the amount depending on zone. 


\section{ORDER BLANK.}

\section{S. C. A'THERTON,}

Greenwood, Delaware.

Send to

R. F. D.

Post Office

Box

Ship by

Shipping Station

County or Street

Date of this order Ship about Amt. enclosed-

Check \$_-_._. Money Order \$.

Stamps $\$$

Cash $\$$

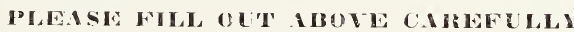

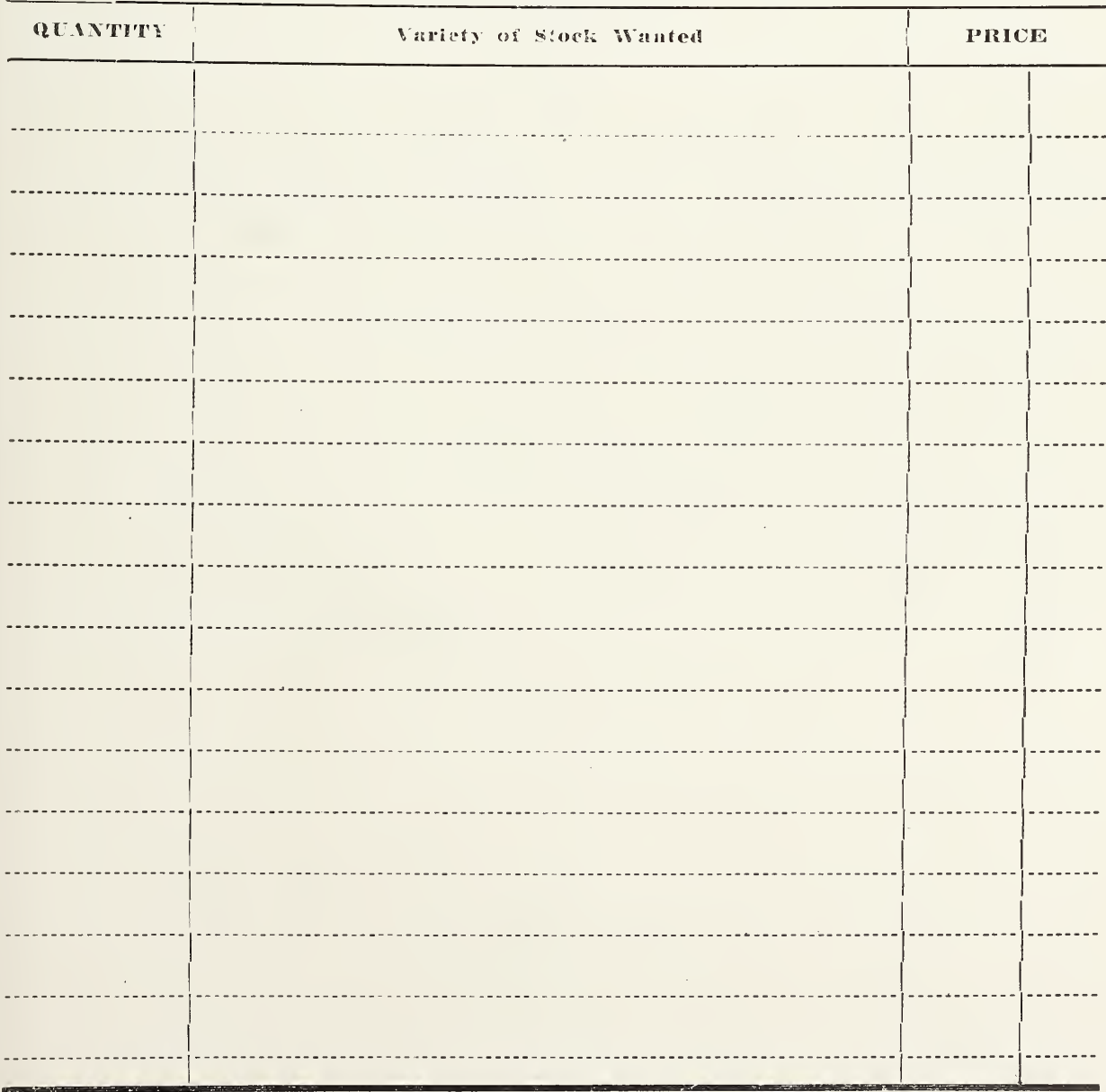



